\title{
Notes
}

\section{Development of RT-PCR Based Method for Detecting Five Non-reported Quarantine Plant Viruses Infecting the Family Cucurbitaceae or Solanaceae}

\author{
Jong-Seung Lee ${ }^{1}$, Won Kyong Cho ${ }^{1}$, Su-Heon Lee ${ }^{2}$, Hong-Soo Choi ${ }^{2}$ and Kook-Hyung Kim ${ }^{1 *}$ \\ ${ }^{1}$ Department of Agricultural Biotechnology and Plant Genomics and Breeding Institute, Seoul National University, Seoul 151- \\ 921, Korea \\ ${ }^{2}$ Department of Agricultural Biology, National Academy of Agricultural Science, RDA, Suwon 441-707, Korea \\ (Received on December 10, 2010; Accepted on Jamuary 24, 2011)
}

\begin{abstract}
For quarantine purpose, we selected five plant RNA viruses including Cucumber vein yellowing virus (CVYV), Cucurbit yellow stunting disorder virus (CYSDV), Potato aucuba mosaic virus (PAMV), Potato yellow dwarf virus (PYDV), and Tomato chlorosis virus (ToCV), which are not reported in Korea and cause serious economic losses to the family Cucurbitaceae or Solanaceae. To detect those viruses, we employed RT-PCR technique with specific oligonucleotide primer pairs and tested their detection efficiency for each virus. To design RT-PCR primers, coat protein was used for CVYV, CYSDV, and ToCV whereas RNA polymerase and nucleocapsid regions were used for PAMV and PYDV, respectively. The development of an RT-PCR based method proved a useful tool for rapid detection and identification of quarantine virus infections.
\end{abstract}

Keywords : Cucurbitaceae, quarantine, RT-PCR, Solanaceae

With increasing volume of worldwide trade, various kinds of plants are being imported to the Korea. Thus, it is likely that potential or unidentified pathogens, specifically, plant viruses, can be imported with host plant materials including crops, feeds, hard woods, seedlings, vegetables, fruits, and medicinal herbs. Currently, the import of some host plants with high susceptibility to various viruses is strictly inhibited by the National Plant Quarantine Service (NPQS). However, foreign plant viruses which are not reported in Korea can also be imported via unknown host plants because the host range for many plant viruses is not well known.

To prevent introduction of non-reported plant viruses from other countries, it is necessary to prepare a specific, sensitive, and fast detection method for quarantine. One of known approaches, reverse transcription-polymerase chain reaction (RT-PCR) based method is the superior than others

\footnotetext{
*Corresponding author.

Phone) +82-2-880-4677, FAX) +82-2-873-2317

E-mail)kookkim@snu.ac.kr
}

(Park and Kim, 2004). For the RT-PCR based diagnostic detection system, we initiated a study to develop specific primer pairs for RT-PCR detection of quarantine plant viruses which are not reported in Korea and might be introduced via imported plant materials.

Among various quarantine plant viruses, we first selected five plant single-strand RNA viruses including Cucumber vein yellowing virus (CVYV) (Janssen et al., 2007), Cucurbit yellow stunting disorder virus (CYSDV) (Yakoubi et al., 2007), Potato aucuba mosaic virus (PAMV) (Manoussopoulos, 2001), Potato yellow dwarf virus (PYDV) (Ghosh et al., 2008), and Tomato chlorosis virus (ToCV) (Wintermantel et al., 2005) causing serious economic losses in plant species belonging to the family Cucurbitaceae or Solanaceae. They belong to the different genus and family and show distinct biological characteristics as summarized in Table 1. For instance, CYSDV and ToCV are member of the genus Crinivirus belonging to the family Closteroviridae while CVYV, PAMV, and PYDV are member of the genus Ipomovirus, Potexvirus, and Nucleorhabdovirus belonging to the families Potyviridae, Alphaflexiviridae, and Rhabdoviridae, respectively (ICTV, 2010). While three viruses including CVYV, CYSDV, and ToCV are usually transmitted by Bemisia tabaci (Berdiales et al., 1999; Martínez-García et al., 2004; Morris et al., 2006), the casual vectors for PAMV and PYDV are aphid and insect Agallia constricta (Ghosh et al., 2008; Manoussopoulos, 2001). CVYV and CYSDV infect numerous host plants, especially, the Cucurbitaceae family including cucumber, melon, and pumpkin (Janssen et al., 2007; Yakoubi et al., 2007). In contrast, PAMV, PYDV, and ToCV infect the Solanaceae family including potato and tomato (Bandyopadhyay et al., 2010; de Bokx, 1975; Louro et al., 2000).

It has been reported that occurrence of all five viruses in southern Europe including Spain and Portugal leads to the huge economic losses (Cuadrado et al., 2001; Font et al., 2004; Louro et al., 2000; Lozano et al., 2004). For instance, since the first outbreak of ToCV in the Málaga and Almería, Spain, ToCV infecting tomato with foliar chlorosis has 
Table 1. List of plant viruses assayed for quarantine

\begin{tabular}{|c|c|c|c|c|c|c|}
\hline Plant virus name & Genus & Family & Type & $\begin{array}{c}\text { No. of } \\
\text { RNA } \\
\text { genomes }\end{array}$ & $\begin{array}{l}\text { No. of } \\
\text { ORFs }\end{array}$ & Host plants \\
\hline $\begin{array}{l}\text { Cucumber vein yellowing } \\
\text { virus (CVYV) }\end{array}$ & Ipomovirus & Potyviridae & $\begin{array}{l}\text { ssRNA } \\
(+) \text {-strand }\end{array}$ & 1 & 1 & $\begin{array}{l}\text { Cucumber, melon, pumpkin, } \\
\text { watermelon }\end{array}$ \\
\hline $\begin{array}{l}\text { Cucurbit yellow stunting } \\
\text { disorder virus (CYSDV) }\end{array}$ & Crinivirus & Closteroviridae & $\begin{array}{l}\text { ssRNA } \\
(+) \text {-strand }\end{array}$ & 2 & 12 & Cucumber, melon, pumpkin \\
\hline $\begin{array}{l}\text { Potato aucuba mosaic } \\
\text { virus (PAMV) }\end{array}$ & Potexvirus & Alphaflexiviridae & $\begin{array}{l}\text { ssRNA } \\
(+) \text {-strand }\end{array}$ & 1 & 6 & Potato, pepper, tomato \\
\hline $\begin{array}{l}\text { Potato yellow dwarf virus } \\
\text { (PYDV) }\end{array}$ & Nucleorhabdovirus & Rhabdoviridae & $\begin{array}{l}\text { ssRNA } \\
(-) \text {-strand }\end{array}$ & 1 & 7 & Potato, daisy, crimson clove \\
\hline $\begin{array}{l}\text { Tomato chlorosis virus } \\
\text { (ToCV) }\end{array}$ & Crinivirus & Closteroviridae & $\begin{array}{l}\text { ssRNA } \\
(+) \text {-strand }\end{array}$ & 2 & 13 & $\begin{array}{l}\text { Tomato, sweet pepper, zinnia, } \\
\text { black night shade }\end{array}$ \\
\hline
\end{tabular}

Table 2. Nucleotide sequences of oligonucleotide primers used for RT-PCR to detect five quarantine plant viruses

\begin{tabular}{|c|c|c|c|c|c|c|c|c|}
\hline Index & Name & $\begin{array}{l}\text { Amplified } \\
\text { region }\end{array}$ & $\begin{array}{c}\text { Nucleotide } \\
\text { accession No. }\end{array}$ & Primer sequences & Length & $\begin{array}{l}\mathrm{Tm} \\
\left({ }^{\circ} \mathrm{C}\right)\end{array}$ & $\begin{array}{l}\text { Expected } \\
\text { size }\end{array}$ & $\begin{array}{c}\text { RT-PCR } \\
\text { result }\end{array}$ \\
\hline 1 & 1 F & t & 41 & GAATGGC & & 55.8 & $\mathrm{p}$ & fic \\
\hline 2 & $-1 \_\mathrm{R}$ & in & 41 & $r G$ & & 56.4 & & ific \\
\hline 3 & CVYV-2_F & Coat $\mathrm{p}$ & C_006941 & 5'-GGCACAAGTGATGAGAGGA & $2 J$ & 56.4 & $331 \mathrm{bp}$ & cific \\
\hline 4 & CVYV-2_R & Coat & 41 & 5'-CATTAGCGGCAAGTGTCTGG & & 59.1 & $31 \mathrm{bp}$ & ific \\
\hline 5 & CYSDV-1_F & Coat protein & & 5'-GGACGGCTC & & 55.7 & & cific \\
\hline 6 & CYSDV-1_R & Coat & 00 & ГААТАТТТСТТ & 26 & 50.9 & $301 \mathrm{bp}$ & cific \\
\hline 7 & CYSDV-2_F & Coat $\mathrm{p}$ & 681 & 5'-CATGCACGG & 22 & 59 & $289 \mathrm{bp}$ & cific \\
\hline 8 & CYSDV-2_R & Coat protein & & 5'-CAAAGCCTGC & 22 & 58.1 & & ific \\
\hline 9 & & & & & & 52.8 & & ific \\
\hline 10 & PAMV-1_R & RNA $p$ & $\mathrm{NC}$ & 5 -TCC & 22 & 53.4 & $338 \mathrm{bp}$ & cific \\
\hline 11 & PAMV-2_F & RNA poly & & 5'-GCA & 22 & 57.3 & & pecifi \\
\hline 12 & & & & & & 58.1 & & \\
\hline 13 & PYDV-1_F & Nucleocapsid & EU183122 & 5'-CGCTCAGTTC & 20 & 56 & $196 \mathrm{bp}$ & cific \\
\hline 14 & PYDV-1_R & Nucleocapsid & EU1 & 5'-TCTGATTCTA & 21 & 54.2 & $196 \mathrm{bp}$ & cific \\
\hline 15 & PYDV-2_F & Nucle & FUU1 & 5'-GAT & 1 & 56.8 & $\mathrm{bp}$ & cific \\
\hline 16 & PYDV-2_R & Nucleocapsid & EU183122 & 5'-GGTAATGGCTGGCAGTCCA-3' & & 55.4 & & ecific \\
\hline 17 & PYDV-3_F & Nucle & GU & 5'-GT & 21 & 51.3 & $192 \mathrm{bp}$ & Unspecific \\
\hline 18 & PYDV-3_R & Nucleos & GU734660 & 5'-CTCCGGATTGTAGAGCAGCAT-3' & 21 & 55.6 & $192 \mathrm{bp}$ & Unspecifi \\
\hline 19 & ToCV-1_F & Coat $p$ & FM2C & 5'-GAGC & 22 & 56.2 & & cific \\
\hline 20 & ToCV-1_R & Coat protein & FM206381 & 5'-CTGAGATATTCATCAACGAACCAT-3' & 24 & 53.8 & & Specific \\
\hline 21 & ToCV-2_F & Coat protein & DQ234675 & 5'-CAGAACTTGGGCAGGAGGGAC-3' & 21 & 59.4 & $354 \mathrm{bp}$ & Unspecific \\
\hline 22 & ToCV-2_R & Coat protein & DQ234675 & 5'-CCACTTAAATCTCGCACCATC-3' & 21 & 53.5 & $354 \mathrm{bp}$ & Unspecifi \\
\hline
\end{tabular}

gradually become a strong epidemic virus especially in southern and eastern regions of Spain (Font et al., 2004). During the last few years, ToCV has spread to new locations and plants such as sweet pepper (Lozano et al., 2004). In addition, cucumber grown in greenhouse, Almeria (Spain), was heavily damaged by CVYV during the year 2000 (Cuadrado et al., 2001).

Five plant viruses used in this study were obtained from DSMZ GmbH, plant virus collection (Braunschweig, Germany) as virus infected dried plant tissues or total plant nucleic acid extracts stored at $-20{ }^{\circ} \mathrm{C}$. All viruses were imported upon permission from NPQS and all experiments were performed under close collaboration with NPQS staff. Total RNAs were extracted from virus infected plant tissues as well as healthy leaves of $N$. benthamiana and tomato using Trizol Reagent ${ }^{\mathbb{R}}$ (Molecular Research Center, Inc., USA) followed by phenol:chloroform:isoamylalcohol (25:24:1) extraction and ethanol precipitation based on the previous study (Park and Kim, 2004). The quality and quantity of extracted total RNAs were analyzed by agarose gel 
electrophoresis and the NanoPhotometer ${ }^{\mathrm{TM}}$ (Implen GmbH, Germany).

To design RT-PCR primers, we retrieved nucleotide sequences of individual viruses from National Center for Biotechnology Information (NCBI). In case of CVYV, CYSDV, and ToCV, RNA region for coat protein (CP) which is highly conserved within the virus species was used to design RT-PCR primers. For the detection of PAMV which is composed of six open reading frames (ORFs), sequences for putative polymerase were employed for RTPCR amplification. RNA sequences for nucleocapsid protein of PYDV which is transcribed from negative strand were selected for specific RT-PCR detection. The expected size of PCR products by RT-PCR ranges from $192 \mathrm{bp}$ to 354 bp. For PYDV, three different primer pairs were designed (Table 2). Detailed information for individual primer was listed in Table 2. All primers were manufactured by Bioneer (Korea).

In prior to perform RT-PCR, the quality of isolated total RNAs was evaluated on $1 \%$ agarose gel stained with ethidium bromide $(\mathrm{EtBr})$. As shown Fig. 1A, all extracted total RNAs displayed very good quality. Using the isolated total RNAs as a template, we synthesized cDNA as follows. First, $2 \mu \mathrm{g}$ extracted total RNAs $(5 \mu \mathrm{l}), 10 \mathrm{pmol}(1 \mu \mathrm{l})$ each reverse primer, $3 \mu 12.5 \mathrm{mM}$ dNTPs, and $6 \mu 1$ DEPC treated $\mathrm{dH}_{2} \mathrm{O}$ were added and incubated at $65^{\circ} \mathrm{C}$ for $5 \mathrm{~min}$. And 100 units M-MLV reverse transcriptase (RT), M-MLV 5X buffer $(5 \mu \mathrm{l})$, and $4.5 \mu \mathrm{l}$ DEPC treated $\mathrm{dH}_{2} \mathrm{O}$ were added to RNA/nucleotide/primer mixture (Promega, USA). RT reaction was carried out at $42{ }^{\circ} \mathrm{C}$ for $1 \mathrm{~h}$. To terminate RT reaction, samples were subsequently incubated at $80^{\circ} \mathrm{C}$ for $3 \mathrm{~min}$. To amplify PCR fragment from individual cDNA, a total of $50 \mu 1$ PCR mixture was prepared by including $2 \mu \mathrm{l}$ cDNA mixture, $5 \mu 1$ 10X buffer, $3 \mu 12.5 \mathrm{mM}$ dNTPs, $2 \mu 1$ each primer pairs (Table 2), $37.5 \mu 1 \mathrm{dH}_{2} \mathrm{O}$, and 2.5 unit Taq DNA polymerase (Takara, Japan). PCR products were amplified for 30 cycles using a Peltier Thermal Cycler (MJ Research, USA) with following steps: denaturation at $92{ }^{\circ} \mathrm{C}$ for $20 \mathrm{~s}$,

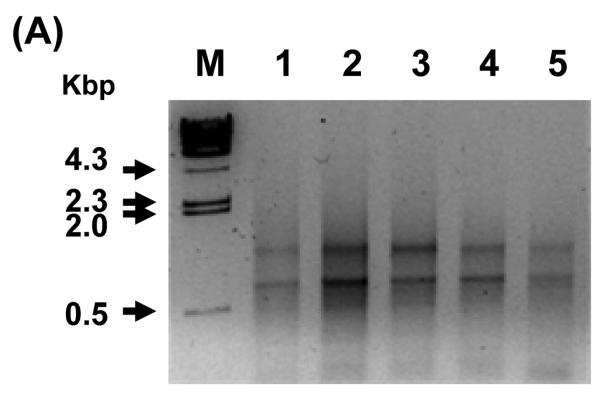

(B)

$\begin{array}{llllllll}M & 1 & 2 & 3 & 4 & 5 & 6 & 7\end{array}$

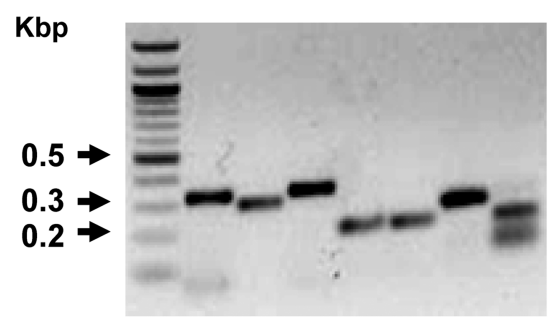

Fig. 1. Isolation of total RNAs and RT-PCR amplification of virus-specific dsDNA fragments using newly developed primer pairs. (A) Agarose gel electrphoresis of isolated total RNAs from virus infected plant leaves. Lanes 1-5 represent total RNAs extracted from CVYV, CYSDV, PAMV, PYDV, and ToCV infected plant tissues. (B) RT-PCR amplification of virus-specific dsDNA fragments using virus-specific primer pairs. Lanes 1-7 represents amplified DNA fragments using CVYV-1, CYSDV-1, PAMV-1, ToCV-1, PYDV-1, PYDV-2, and PYDV-3 specific primers, respectively. $\mathrm{M}$ indicates lamda DNA molecular marker digested with HindIII (600 ng/5 $\mu \mathrm{l})$.

annealing at $53{ }^{\circ} \mathrm{C}$ for $1 \mathrm{~min}$, extension at $72{ }^{\circ} \mathrm{C}$ for $1 \mathrm{~min}$, and a final extension $72{ }^{\circ} \mathrm{C}$ for $10 \mathrm{~min}$. Five $\mu 1$ of amplified PCR products were separated on $1 \%$ agarose gel by electrophoresis, visualized by staining with $0.5 \mu \mathrm{g} / \mathrm{ml} \mathrm{EtBr}$, and observed under UV illumination.

Initially, we performed PCR using the synthesized cDNA as a template at $53{ }^{\circ} \mathrm{C}$ for $30 \mathrm{sec}$ as an annealing temperature. PCR results demonstrated that all primer pairs could successfully amplify specific fragments except for PYDV-3

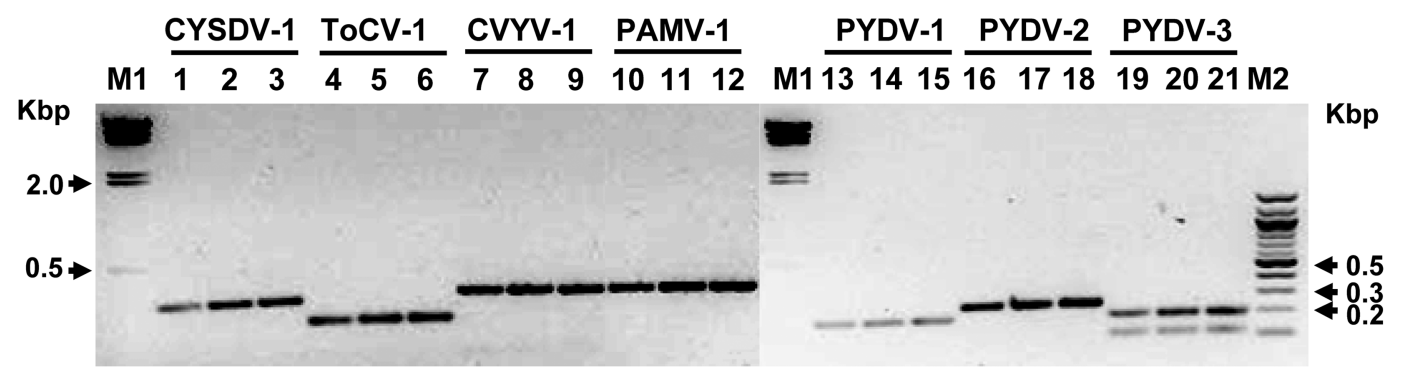

Fig. 2. Gradient RT-PCR to improve specificity and sensitivity of primer pairs. M1 indicates lamda DNA molecular marker digested with HindIII $(600 \mathrm{ng} / 5 \mu \mathrm{l})$ whereas M2 indicates $100 \mathrm{bp}$ DNA ladder purchased from NEB, UK. Three different annealing temperatures, i.e. $50{ }^{\circ} \mathrm{C}$ (lanes $1,4,7,10,13,16$, and 19 ), $53.2^{\circ} \mathrm{C}$ (lanes $2,5,8,11,14,17$, and 20 ), and $56.7^{\circ} \mathrm{C}$ (lanes $3,6,9,12,15,18$, and 21 ) were tested for each primer pairs. 


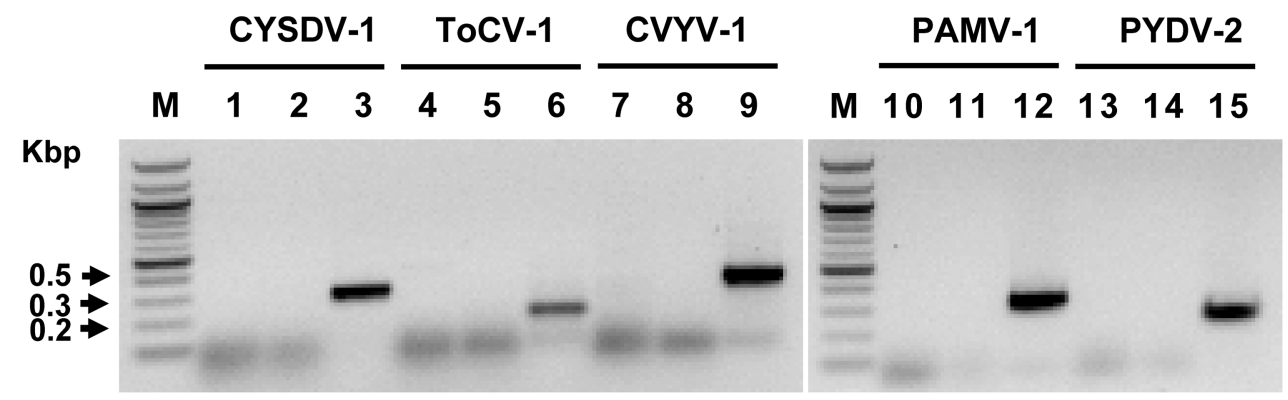

Fig. 3. Specificity of newly designed primers for virus detection by RT-PCR. Amplified dsDNA fragments were separated in an $1 \%$ agarose gel and stained with EtBr. cDNAs prepared using healthy $N$. benthamiana (lanes 1, 4, 7, 10, and 13), healthy tomato (lanes 2, 5, 8, 11 , and 14), and virus infected leaves (lanes 3, 6, 9, 12, and 15) were used for PCR reaction with each primer pairs. M indicates 100 bp DNA ladder purchased from NEB, UK.

primer pairs which amplified two PCR products (Fig. 1B). To increase specificity of primer binding, we performed gradient PCR by changing annealing temperature from $50{ }^{\circ} \mathrm{C}, 53.2^{\circ} \mathrm{C}$, and $56.7^{\circ} \mathrm{C}$ (Fig. 2). In general, increased annealing temperature led to amplify high amount of PCR product. However, we failed to get a single specific amplified fragment with a PYDV-3 primer pair (Fig. 2).

To test virus specificity of newly designed primer pairs, we also isolated total RNAs from leaves of healthy $N$. benthamiana and tomato. RT-PCR confirmed that the virus specific primer pairs could detect each virus only from virus infected plant leaves not from healthy $N$. benthamiana and tomato (Fig. 3). In addition, we also designed an additional primer pairs for four viruses except PYDV. The other CP region for CVYV, CYSDV, and $\mathrm{ToCV}$, and polymerase region for PAMV were used for primer design. The newly designed primers have an annealing temperature range from $53.5^{\circ} \mathrm{C}$ to $59.4{ }^{\circ} \mathrm{C}$ for Tm (Table 2). At $53{ }^{\circ} \mathrm{C}$ for annealing temperature, only CYSDV-2 primer set amplified an expected band while unspecific several bands were amplified with other primer sets indicating that annealing temperature should be adjusted to amplify specific band for each quarantine virus (Fig. 4A). To further clarify annealing temperature for each primer pair tested, we performed PCR reaction at $56^{\circ} \mathrm{C}$. PCR results showed that CVYV-2 and CYSDV-2 could amplify an expected specific band, respectively (Fig. 4B). However, we failed to get single bands from PAMV and ToCV primer pairs showing strong unspecific bands. From these studies, we could develop two efficient primer pairs for CVYV, CYSDV, and PYDV, and one primer pair for PAMV and ToCV. The optimal annealing temperature for all primer pairs was determined as $56^{\circ} \mathrm{C}$. Furthermore, to check specificity of newly designed primer pairs among various plant virus species, we used other plant viruses mostly infecting plants belonging to the family Cucurbitaceae and Solanaceae including Cucumber mosaic virus (CMV), Potato virus $X(\mathrm{PVX})$ and Tomato spotted wilt virus (TSWV). RT-PCR results clearly displayed that there were no amplified fragments from CMV, PVX and TSWV infected samples using the newly designed primer pairs (data not shown).

In general, virus specific RT-PCRs and serological approaches were widely used to detect viruses. As compared to serological approaches which require many experimental steps and time to produce anti-body, RT-PCR is simple, speedy, reproducible, and accurate. For the western blot or enzyme-linked immunosorbent assay (ELISA), extremely large sample amounts are required while only small sample

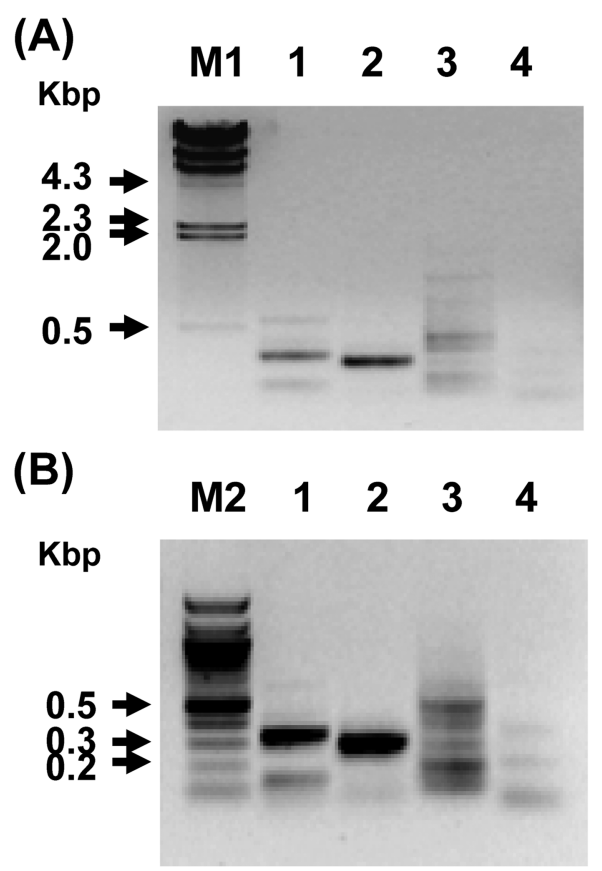

Fig. 4. Optimization of annealing temperature for RT-PCR. Two different annealing temperatures, $53{ }^{\circ} \mathrm{C}(\mathrm{A})$ and $56^{\circ} \mathrm{C}(\mathrm{B})$, were tested for PCR using each primer pairs. Lanes 1-4 represent amplified dsDNA fragments using CVYV-2, CYSDV-2, PAMV2 , and ToCV-2 primers, respectively. M1 indicates lamda DNA molecular marker digested with HindIII $(600 \mathrm{ng} / 5 \mu \mathrm{l})$ whereas M2 indicates 100 bp DNA ladder purchased from NEB, UK. 
such as a small piece of infected leave is enough for RTPCR. For quarantine purpose, it is necessary to get accurate and specific results as quickly as possible because biological products cannot be retained in the airports and harbors for long time and many samples should be tested in parallel. For those reason, RT-PCR based detection system is superior than other methods.

In this study, a set of new primers for the detection of five non-reported plant viruses were designed and employed for RT-PCR detection of each virus. The specificity of each newly designed primer pairs was evaluated by RT-PCR assay. We identified at least one primer pairs which can amplify one specific band for individual plant virus. Moreover, we tested various annealing temperature for PCR and high annealing temperature often led to increase the amount of PCR products and specificity. The successful application of newly developed RT-PCR primer pairs will be usefully used to detect five quarantine plant viruses.

\section{Acknowledgments}

This research was supported in part by grants from the Korea Institute of Planning and Evaluation for Technology of Food, Agriculture, Forestry and Fisheries (No. 30901504) and from the Rural Development Administration (Nos. PJ006952 \& PJ007412). JSL and WKC were supported by the fellowships from the MEST through Brain Korea 21 Project.

\section{References}

Bandyopadhyay, A., Kopperud, K., Anderson, G, Martin, K. and Goodin, M. M. 2010. An integrated protein localization and interaction map for Potato yellow dwarf virus, type species of the genus Nucleorhabdovirus. Virology 402:61-71.

Berdiales, B., Bernal, J. J., Sâez, E., Woudt, B., Beitia, F. and Rodríguez-Cerezo, E. 1999. Occurrence of Cucurbit yellow stunting disorder virus (CYSDV) and Beet pseudo-yellows virus in cucurbit crops in spain and transmission of CYSDV by two biotypes of Bemisia tabaci. Eur. J. Plant Pathol. 105:211-215.

Cuadrado, I. M., Janssen, D., Velasco, L., Ruiz, L. and Segundo, E. 2001. First report of Cucumber vein yellowing virus in Spain. Plant Dis. 85:336.

de Bokx, J. A., 1975. Reactions of various plant species to inocu- lation with Potato aucuba mosaic virus. Potato Res. 18:397409.

Font, M. I., Juárez, M., Martínez, O. and Jordá, C. 2004. Current status and newly discovered natural hosts of Tomato infectious chlorosis virus and Tomato chlorosis virus in Spain. Plant Dis. $88: 82$.

Ghosh, D., Brooks, R. E., Wang, R., Lesnaw, J. and Goodin, M. M. 2008. Cloning and subcellular localization of the phosphoprotein and nucleocapsid proteins of Potato yellow dwarf virus, type species of the genus Nucleorhabdovirus. Virus Res. 135:26-35.

International Committee on Taxonomy of Viruses (ICTV). 2010. Virus Taxonomy: 2009 Release. http://www.ictvonline.org/ virusTaxonomy.asp?version $=2009$.

Janssen, D., Velasco, L., Martín, G, Segundo E. and Cuadrado, I. M. 2007. Low genetic diversity among Cucumber vein yellowing virus isolates from spain. Virus Genes 34:367-371.

Louro, D., Accotto, G. P. and Vaira, A. M. 2000. Occurrence and diagnosis of Tomato chlorosis virus in portugal. Eur. J. Plant Pathol. 106:589-592.

Lozano, G, Moriones, E. and Navas-Castillo, J. 2004. First report of sweet pepper (Capsicum annuum) as a natural host plant for Tomato chlorosis virus. Plant Dis. 88:224.

Manoussopoulos, I. N. 2001. Acquisition and retention of Potato virus $y$ helper component in the transmission of Potato aucuba mosaic virus by aphids. J. Phytopathol. 149:103-106.

Martínez-García, B., Marco, C. F., Goytia, E., López-Abella, D., Serra, M. T., Aranda M. A. and López-Moya, J. J. 2004. Development and use of detection methods specific for Cucumber vein yellowing virus (CVYV). Eur. J. Plant Pathol. 110:811821.

Park, M.-R. and Kim, K.-H. 2004. RT-PCR detection of three non-reported fruit tree viruses useful for quarantine purpose in Korea. Plant Pathol. J. 20:147-154.

Morris, J., Steel, E., Smith, P., Boonham, N., Spence, N. and Barker, I. 2006. Host range studies for Tomato chlorosis virus and Cucumber vein yellowing virus transmitted by Bemisia tabaci (Gennadius). Eur. J. Plant Pathol. 114:265-273.

Wintermantel, W. M., Wisler, G C., Anchieta, A. G., Liu, H.-Y., Karasev, A. V. and Tzanetakis, I. E. 2005. The complete nucleotide sequence and genome organization of tomato chlorosis virus. Arch. Virol. 150:2287-2298.

Yakoubi, S., Desbiez, C., Fakhfakh, H., Wipf-Scheibel, C., Marrakchi, M. and Lecoq, H. 2007. Occurrence of Cucurbit yellow stunting disorder virus and Cucumber vein yellowing virus in Tunisia. J. Plant Pathol. 89:417-420. 